National Water Quality Program

National Water-Quality Assessment Project

\title{
Groundwater Quality in the Ozark Plateaus Aquifer System, Central United States
}

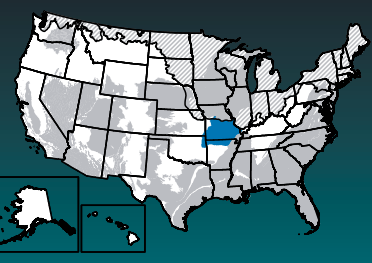

Groundwater provides nearly 50 percent of the Nation's drinking water. To help protect this vital resource, the U.S. Geological Survey (USGS) National Water-Quality Assessment (NAWQA) Project assesses groundwater quality in aquifers that are important sources of drinking water (Burow and Belitz, 2014). The Ozark Plateaus aquifer system constitutes one of the important aquifer systems being evaluated.

\section{Background}

The Ozark Plateaus aquifer system underlies an area of about 49,000 square miles, including much of southern Missouri, northwestern Arkansas, and relatively small parts of Kansas and Oklahoma. About 4 million people reside in areas overlying this aquifer system, and about 212 million gallons per day of groundwater was withdrawn for public and domestic supply in 2010 (Hays and others, 2016; Arnold and others, 2020a). Land use in the area overlying the Ozark Plateaus aquifer system is primarily agricultural ( 35 percent) and natural land cover (58 percent) with a small percentage (7 percent) of urban and other developed land (Homer and others, 2015). St. Louis and Springfield, Missouri, are the largest cities overlying this aquifer system.

The Ozark Plateaus aquifer system consists of three regional aquifers - the Springfield Plateau, Ozark, and St. Francois aquifers - separated by confining units (Miller and Appel, 1997; Renken, 1998). The primary lithologies of the formations that make up the aquifers are limestone and dolomite and to a lesser extent sandstone. The Springfield Plateau aquifer is the uppermost aquifer of this aquifer system, and wells usually produce 20 gallons per minute or less (Miller and Appel, 1997). The Ozark aquifer is the primary water-bearing unit in this aquifer system, and most of the wells sampled for this study were completed in this aquifer. The lowermost St. Francois aquifer has limited use in Arkansas because of its depth and the availability of water in the shallower aquifers. The St. Francois aquifer is used primarily where it is near land surface in Missouri (Miller and Appel, 1997). The carbonate rocks that make up these aquifers are susceptible to dissolution, and as a result, karst features such as sinkholes, springs, and caves are common across this aquifer system. Recharge to these aquifers is primarily from infiltration of rainfall, but sinkholes provide areas of focused recharge (Renken, 1998)

Groundwater quality in the Ozark Plateaus aquifer system was evaluated by sampling 60 publicsupply wells, completed in the Ozark or the St. Francois aquifer, that were randomly distributed in an equal area grid. In one grid cell, no wells were available, and a substitute well was sampled outside of the study area boundary in an area where the Ozark aquifer extends below overlying units. Waterquality data collected from wells in a network designed in this way are representative of the spatial distribution of the water quality in the study area (Belitz and others, 2010). Results from these wells were used to estimate the percentage of the study area with high, moderate, and low concentrations with respect to constituent benchmarks. The accuracy of the estimates depends upon the distribution and number of wells, not on the size of the area (Belitz and others, 2010). The wells ranged from about 370 to 3,420 feet (ft) deep with an average depth of about $1,180 \mathrm{ft}$. Samples were collected between April and August 2016 and analyzed for a large number of natural and man-made constituents.

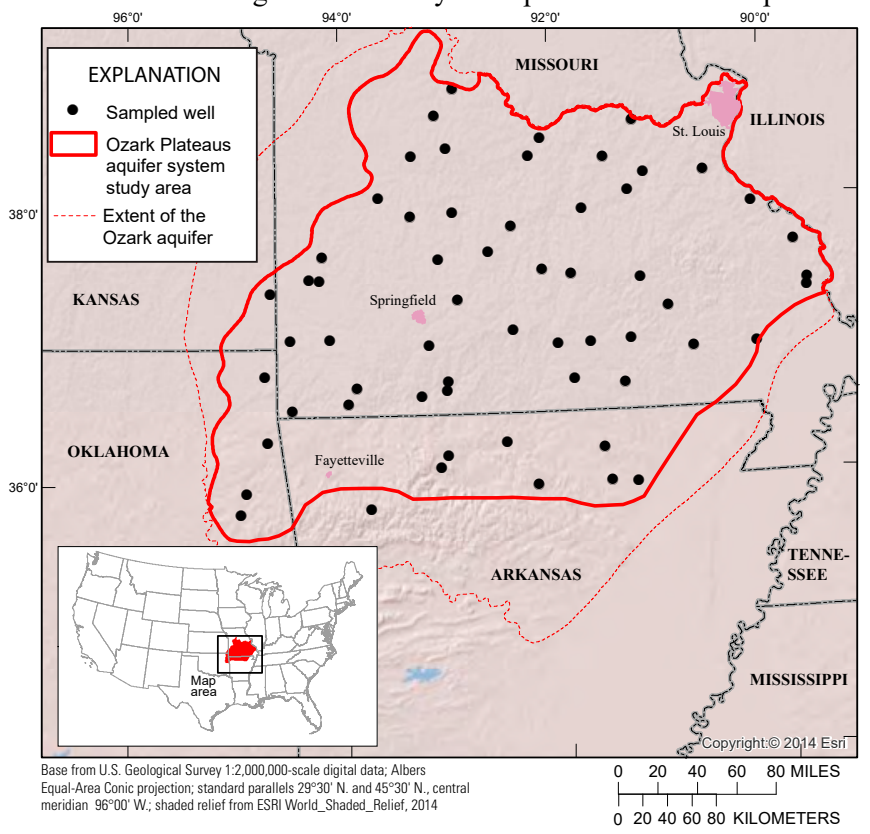

\section{Overview of Water Quality}

\section{Inorganic constituents}

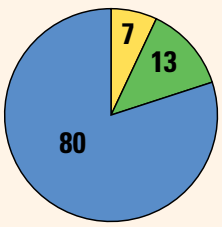

\section{CONSTITUENT CONCENTRATIONS}

$\bigcirc$ High $\bigcirc$ Moderate $\bigcirc$ Low or not detected

Values are a percentage of the study area with concentrations in the three specified categories. Percentages might not sum to $\mathbf{1 0 0}$ because of rounding.

Principal Aquifer Studies (Burow and Belitz, 2014) are designed to evaluate untreated groundwater used for public supply. Groundwater quality is assessed by comparing concentrations to benchmarks established for drinking-water quality. Benchmarks and definitions of high, moderate, and low relative concentrations are discussed in the inset box on page 3 .

Many inorganic constituents are present naturally in groundwater; however, concentrations can be affected by human activities. One or more inorganic constituents with human-health benchmarks were present at high concentrations in about 7 percent of the study area and at moderate concentrations in about 13 percent.

Man-made organic constituents are found in products used in the home, business, industry, and agriculture. Organic constituents can enter the environment through normal use, spills, or improper disposal; however, they were detected infrequently, and concentrations were typically low. No organic constituents with human-health benchmarks were detected at high or moderate concentrations in the study area. 


\section{Results: Groundwater Quality at the Depth Zone Used for Public Supply in the Ozark Plateaus Aquifer System}

\section{INORGANIC CONSTITUENTS}

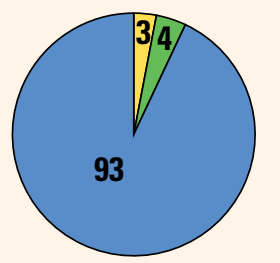

\section{Trace \\ elements and major and minor ions}
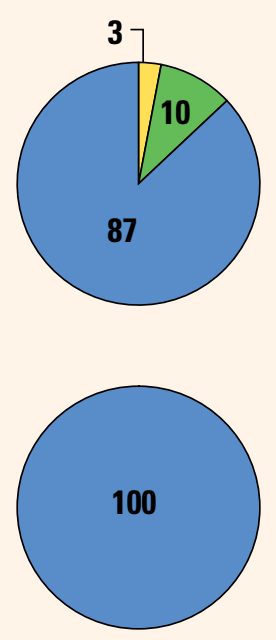

\section{Radioactive constituents}

\section{Nutrients}

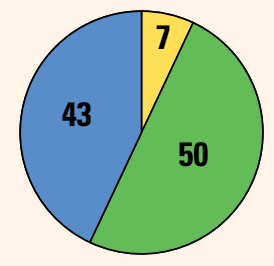

\section{Inorganic Constituents With Human-Health Benchmarks}

Trace elements and major and minor ions are present naturally in the minerals of rocks, soils, and sediments and in the water that comes into contact with those materials. Samples were analyzed for 34 trace elements and major and minor ions, of which 22 have human-health benchmarks (healthbased screening level [HBSL] benchmarks were updated in 2018 to include aluminum, cobalt, and iron). These constituents were detected at high concentrations in about 3 percent of the study area (the depth zone used for public supply) and at moderate concentrations in about 4 percent of the study area. Arsenic and strontium were the only trace elements detected at high concentrations.

Radioactivity is the release of energy or energetic particles during the spontaneous decay of unstable atoms, and humans are exposed continuously to small amounts of natural radioactivity. Most of the radioactivity in groundwater comes from the decay chain of naturally occurring isotopes of uranium and thorium. Samples were analyzed for eight radioactive constituents, of which four have human-health benchmarks. Radioactive constituents were present at high levels in about 3 percent of the study area and at moderate levels in about 10 percent of the study area. Gross-alpha activity and radium-226 plus radium-228 were the only radiochemical constituents detected at high concentrations.

Nutrients are present naturally at low concentrations in groundwater; high and moderate concentrations (relative to human-health benchmarks) generally are a result of human activities. Samples were analyzed for five nutrients, of which two (nitrate and nitrite) have human-health benchmarks. Common sources of nutrients, aside from soils, include fertilizer applied to crops and landscaping, seepage from septic systems, and human and animal waste. Nutrients were not present at high or moderate concentrations in the study area.

\section{Inorganic Constituents and Field Measurements With Non-Health Benchmarks}

(Not included in water-quality overview charts shown on the front page)

Some constituents affect the aesthetic properties of water, such as taste, color, and odor, or can create nuisance problems, such as staining and scaling. The benchmarks used for these constituents are non-regulatory secondary maximum contaminant level (SMCL) benchmarks established for public drinking water. Some constituents, such as manganese, have both human-health benchmarks and SMCLs. Samples were analyzed for 11 constituents that have SMCLs. One or more of these constituents were present at high and moderate concentrations in about 7 percent and 50 percent of the study area, respectively.

Total dissolved solids (TDS) concentration is a measure of the salinity of the groundwater based primarily on the concentrations of ions, and all water naturally contains TDS because of the weathering and dissolution of minerals in rocks and sediments. Total dissolved solids concentrations can be high as a result of natural factors or human activities such as road salting and some agricultural activities. Total dissolved solids were present at high concentrations relative to the SMCL in about 3 percent of the study area and at moderate concentrations in 50 percent of the study area. Fluoride was present at high concentrations in about 2 percent and at moderate concentrations in about 3 percent of the study area.

Anoxic conditions in groundwater (low concentrations of dissolved oxygen) can result in the release of naturally occurring iron and manganese from minerals into groundwater. Manganese was present at both high and moderate concentrations relative to the SMCL in about 2 percent of the study area.

In about 2 percent of the study area, the $\mathrm{pH}$ of groundwater was greater than the SMCL of 8.5. High $\mathrm{pH}$ values make the water alkaline, which can affect the taste of water and result in mineral deposits in pipe or plumbing fixtures. 


\section{Results: Groundwater Quality at the Depth Zone Used for Public Supply in the Ozark Plateaus Aquifer System}

\section{ORGANIC CONSTITUENTS}

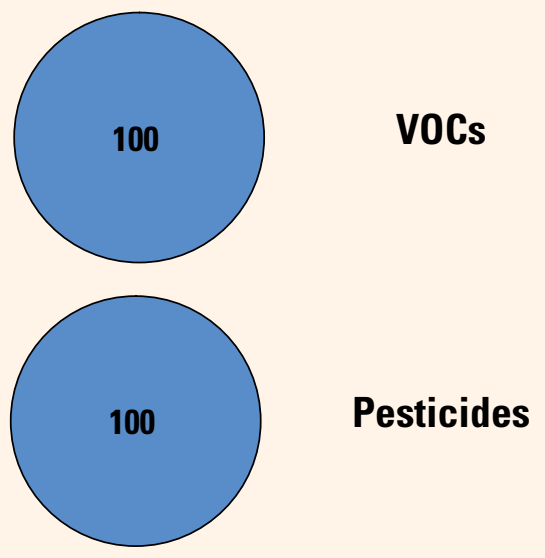

\section{Volatile Organic Compounds With Human-Health Benchmarks}

Volatile organic compounds (VOCs) are present in many household, commercial, industrial, and agricultural products and are characterized by their tendency to volatilize (evaporate) into the air. Samples were analyzed for 85 VOCs, of which 51 have human-health benchmarks. Several volatile organic compounds were detected in the study area, but they were not at moderate or high concentrations relative to human-health benchmarks.

\section{Pesticides With Human-Health Benchmarks}

Pesticides, including herbicides, insecticides, and fungicides, are applied to crops, gardens and lawns, around buildings, and along roads to help control unwanted vegetation (weeds), insects, fungi, and other pests. Samples were analyzed for 225 pesticide compounds (pesticides and their breakdown products), of which 119 have human-health benchmarks. About 10 pesticide compounds were detected in the study area but not at high or moderate concentrations.

\section{BENCHMARKS FOR EVALUATING GROUNDWATER OUALITY}

The USGS NAWQA Project uses benchmarks established for drinking water to provide context for evaluating the quality of untreated groundwater. The quality of water received by customers may be different from results presented herein because after withdrawal, groundwater may be treated prior to delivery. Federal regulatory benchmarks for protecting human health are used for this evaluation of water quality when available. Otherwise, non-regulatory human-health benchmarks and nonregulatory aesthetic benchmarks are used. Not all analyzed constituents have associated benchmarks and thus are not considered in this context. Human-health benchmarks are available for 28 of 55 inorganic constituents and properties and 170 of 310 organic constituents.

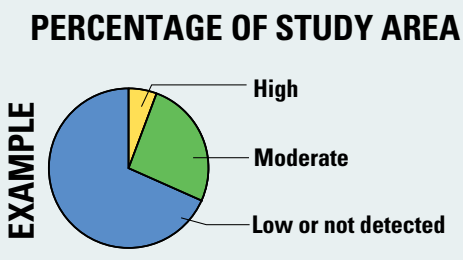

Values are a percentage of the study area with concentrations in the three specified categories. Percentages might not sum to 100 because of rounding.

Concentrations are considered high if they are greater than a human-health benchmark (Norman and others, 2018) or SMCL. For inorganic constituents, concentrations are moderate if they are greater than one-half of a benchmark. For organic constituents, concentrations are moderate if they are greater than one-tenth of a benchmark; this lower threshold was used because organic constituents are generally less prevalent and have smaller concentrations relative to benchmarks than inorganic constituents (Toccalino and others, 2004).

\section{Benchmark Type and Value for Selected Constituents}

This table presents benchmarks for those constituents detected at high concentrations in the Ozark Plateaus aquifer system. Benchmark types are regulatory U.S. Environmental Protection Agency (EPA) maximum contaminant levels (MCLs), non-regulatory health-based screening levels (HBSLs), and non-regulatory EPA secondary maximum contaminant levels (SMCLs).

[ppb, part per billion or microgram per liter $(\mu \mathrm{g} / \mathrm{L})$; ppm, part per million or milligram per liter $(\mathrm{mg} / \mathrm{L})$; $\mathrm{pCi} / \mathrm{L}$, picocurie per liter]

\begin{tabular}{|c|c|c|c|c|c|}
\hline \multirow{2}{*}{ Constituent } & \multicolumn{2}{|c|}{ Benchmark } & \multirow{2}{*}{ Constituent } & \multicolumn{2}{|c|}{ Benchmark } \\
\hline & Type & Value & & Type & Value \\
\hline Flouride & SMCL & $2 \mathrm{ppm}$ & Radium-226 and -228 & MCL & $5 \mathrm{pCi} / \mathrm{L}$ \\
\hline Arsenic & MCL & $10 \mathrm{ppb}$ & Total dissolved solids (TDS) & SMCL & $500 \mathrm{ppm}$ \\
\hline Strontium & HBSL & $4,000 \mathrm{ppb}$ & Manganese & SMCL & $50 \mathrm{ppb}$ \\
\hline Gross-alpha activity & MCL & $15 \mathrm{pCi} / \mathrm{L}$ & $\mathrm{pH}$ & SMCL & $6.5-8.5$ \\
\hline
\end{tabular}


Few Constituent Concentrations Were High Relative to Benchmarks

In contrast to previous water-quality assessments of groundwater quality in the Ozark Plateaus aquifer system that identified high nitrate concentrations in springs and shallow groundwater (Adamski, 1997), concentrations of nitrate and other primarily anthropogenic constituents were not detected at high or moderate concentrations relative to human-health benchmarks. Wells that were sampled as part of this study were considerably deeper than wells sampled for the earlier assessments. In this study, naturally occurring constituents were the only constituents detected at high concentrations relative to benchmarks. Radium was the constituent that was most frequently detected at moderate and high concentrations; however, these elevated concentrations, which were most prevalent in the western part of the study area, occurred in only 7 percent of the study area.

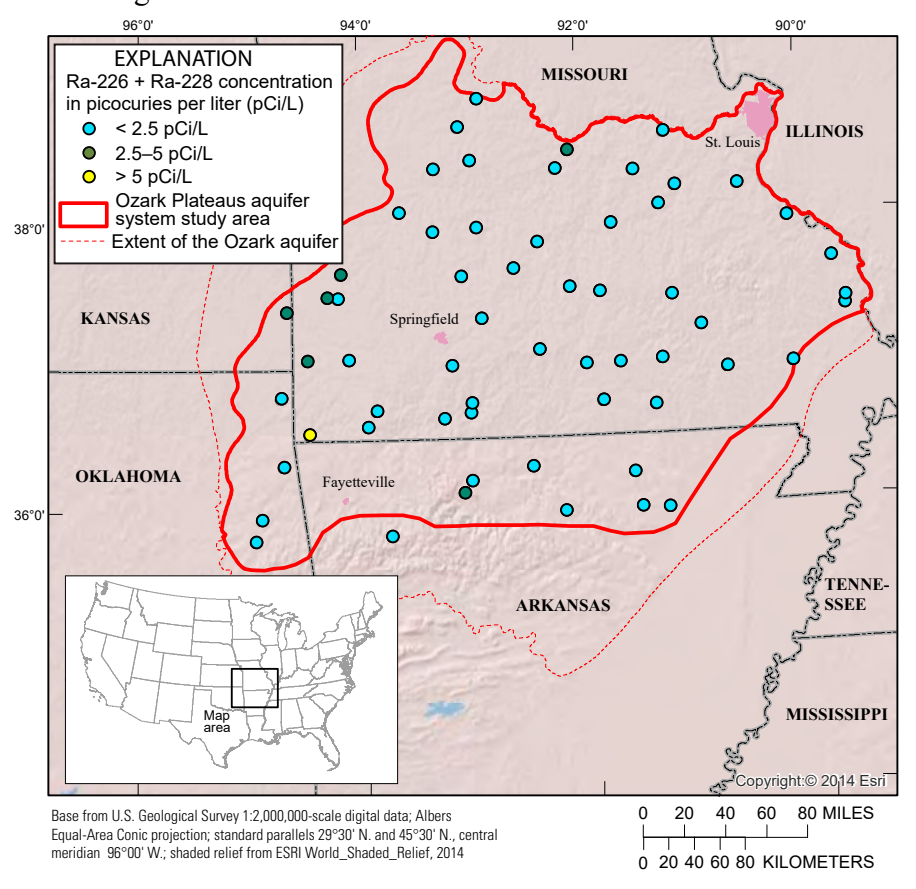

By James A. Kingsbury

\section{REFERENCES CITED}

Adamski, J.C., 1997, Nutrients and pesticides in ground water of the Ozark Plateaus in Arkansas, Kansas, Missouri, and Oklahoma: U.S. Geological Survey Water Resources Investigations Report 96-4313, 28 p., https://doi.org/10.3133/wri964313.

Arnold, T.L., Bexfield, L.M., Musgrove, M., Erickson, M.L., Kingsbury, J.A., Degnan, J.R., Tesoriero, A.J., Kulongoski, J.T., and Belitz, K., 2020a, Groundwater-quality and select quality-control data from the National Water-Quality Assessment Project, January through December 2016, and previously unpublished data from 2013 to 2015: U.S. Geological Survey Data Series 1124, 135 p., https://doi.org/10.3133/ds1124.

Arnold, T.L., Sharpe, J.B., Bexfield, L.M., Musgrove, M., Erickson, M.L., Kingsbury, J.A., Degnan, J.R., Tesoriero, A.J., Kulongoski, J.T., and Belitz, K., 2020b, Datasets from groundwater-quality and select quality-control data from the National Water-Quality Assessment Project, January through December 2016, and previously unpublished data from 2013 to 2015: U.S. Geological Survey data release, https://doi.org/10.5066/P9W4RR74.

Belitz, K., Jurgens B., Landon, M.K., Fram, M.S., and Johnson, T., 2010, Estimation of aquifer scale proportion using equal area grids: Assessment of regional scale groundwater quality: Water Resources Research., v. 46, no. 11, 14 p., https://doi.org/10.1029/2010WR009321.

Burow, K.R., and Belitz, K., 2014, Groundwater studies-Principal aquifer surveys: U.S. Geological Survey Fact Sheet 2014-3024, 2 p., https://doi.org/10.3133/fs20143024.

DeSimone, L.A., McMahon, P.B., and Rosen, M.R., 2014, The quality of our Nation's waters-Water quality in principal aquifers of the United States, 1991-2010: U.S. Geological Survey Circular 1360, 151 p., https://doi.org/10.3133/cir1360.

Hays, P.D., Knierim, K.J., Breaker, B., Westerman, D.A., and Clark, B.R., 2016, Hydrogeology and hydrologic conditions of the Ozark Plateaus aquifer system: U.S. Geological Survey Scientific Investigations Report 2016-5137, 61 p., https://doi.org/10.3133/sir20165137.

Homer, C., Dewitz, J., Yang, L., Jin, S., Danielson, P., Xian, G., Coulston, J., Herold, N., Wickham, J., and Megown, K., 2015, Completion of the 2011 National Land Cover Database for the conterminous United States-Representing a decade of land cover change information: Photogrammetric Engineering and Remote Sensing, v. 81, no. 5, p. 345-354.

Miller, J.A., and Appel, C.L., 1997, Ground water atlas of the United States-Segment 3, Kansas, Missouri, Nebraska: U.S. Geological Survey Hydrologic Atlas 730-D, https://doi.org/10.3133/ha730D.

Norman, J.E., Toccalino, P.L., Morman, S.A., 2018, Health-based screening levels for evaluating waterquality data ( $2 \mathrm{~d}$ ed.): U.S. Geological Survey National Water-Quality Assessment Program web page, https://doi.org/10.5066/F71C1TWP.

Renken, R.A., 1998, Ground water atlas of the United States-Segment 5, Arkansas, Louisiana, Mississippi: U.S. Geological Survey Hydrologic Atlas 730-F, https://doi.org/10.3133/ha730F.

Toccalino, P.L., Norman, J.E., Phillips, R.H., Kauffman, L.J., Stackelberg, P.E., Nowell, L.H., Krietzman, S.J., and Post, G.B., 2004, Application of health-based screening levels to groundwater quality data in a state-scale pilot effort: U.S. Geological Survey Scientific Investigations Report 2004-5174, 64 p., https://doi.org/10.3133/sir20045174.

\section{Principal Aquifer Studies}

The USGS NAWQA Project has been assessing the quality of groundwater since 1991. The NAWQA studies include Land Use Studies (LUS), Major Aquifer Studies (MAS), and Principal Aquifer Studies (PAS). These three study types are based on the sampling of networks of wells distributed across an area of interest. The LUS networks typically consist of observation wells that are relatively shallow; MAS networks typically consist of domestic-supply wells that are intermediate in depth; and PAS networks typically consist of public-supply wells that are relatively deep. A national synthesis of shallow and intermediate depth groundwater quality was reported by DeSimone and others (2014). This fact sheet provides a summary of PAS data for 60 public-supply wells sampled during 2016 in the Ozark Plateaus aquifer system principal aquifer (data available in Arnold and others, 2020b).

The PAS assessments like this one allow for the comparison of constituent concentrations in untreated groundwater with benchmarks established for the protection of human health and for aesthetic qualities for drinking water and also provide a basis for comparison of groundwater quality among principal aquifers.

The data collected by the NAWQA Project include chemical analyses generally not available as part of regulatory compliance monitoring, including measurements at concentrations much lower than humanhealth benchmarks and measurement of constituents that can be used to trace the sources and movement of groundwater.

\section{For more information}

Technical reports and hydrologic data collected for the USGS NAWQA Project may be obtained from

\footnotetext{
NAWQA Chief Scientist

U.S. Geological Survey

12201 Sunrise Valley Drive, MS 413

Reston, VA 20192-0002

Email: nawqapublicinfo@usgs.gov

WEB: https://water.usgs.gov/nawqa/
} 